\title{
Profil Keterampilan Berpikir Kreatif Siswa di Salah Satu SMP Negeri Surakarta
}

\author{
Dilla Rapika, Hafsah Salsabila, Monika Lintang, Sri Lestari, dan Baskoro Adi \\ Prayitno \\ Pendidikan Biologi, Fakultas Pendidikan dan Ilmu Keguruan, Universitas Sebelas \\ Jl. Ir. Sutami No.36A, Jebres, Kota Surakarta, Jawa Tengah \\ e-mail: dillarapikas@student.uns.ac.id, hafsahsalsabila@student.uns.ac.id, \\ monikalintanglaksmi@gmail.com, sriilestarii53@ student.uns.ac.id, \\ baskoro_ap@uns.ac.id
}

\begin{abstract}
Abstrak
Penelitian ini bertujuan untuk mengetahui profil keterampilan berpikir kreatif siswa di salah satu SMP Negeri di Surakarta. Metode yang digunakan dalam penelitian ini adalah metode deskriptif kuantitatif. Populasi penelitian ini adalah seluruh siswa kelas VII dan VIII di salah satu SMP Negeri di Surakarta. Teknik sampling menggunakan stratified random sampling dengan jumlah sampel sebanyak 50 siswa. Keterampilan berpikir kreatif diukur menggunakan tes tertulis yang dikembangkan oleh Dian Purnama Sari (2017). Indikator keterampilan berpikir kreatif yang diukur meliputi kelancaran, keluwesan, keaslian, dan keterincian. Teknik analisis data menggunakan statistik deskriptif. Hasil penelitian menunjukkan keterampilan berpikir siswa secara umum dalam kategori cukup kreatif, dengan capaian indikator kelancaran sebesar 1,4, keluwesan sebesar 1, keaslian sebesar 1,6, dan keterincian sebesar 1.

Kata Kunci-Berpikir, Biologi, Kreatif, Kreativitas, Siswa SMP.
\end{abstract}

\begin{abstract}
This study aims to determine the creativity students in one of the State Junior High School (JHS) in Surakarta. The method used in this research is descriptive method. The population in this study is all students of class VII and VIII SMP. The sampling technique uses stratified random sampling with the number of samples are 50 students. Creative thinking skills using written tests which developed by Dian Purnaman Sari (2017). Creative indicators consisting of fluency, flexibility, authenticity and detail. Data analysis techniques use descriptive statistics. The results showed that the level creativity of student in creative enough category, with level of fluency: 1,4, flexibility: 1, authenticity: 1,6, and detail: 1 .
\end{abstract}

Keywords: Biology, Creative, Creativity, Junior High School Students, Thinking.

\section{PENDAHULUAN}

Setiap manusia pada dasarnya adalah makhluk kreatif. Istilah kreatif dan kreativitas kerap digunakan beriringan. Kreativitas merupakan hasil dari berpikir kreatif. Kreativitas adalah hasil dari interaksi antara individu dan lingkungannya (Munandar, 2009). Seseorang mempengaruhi dan dipengaruhi oleh lingkungan dimana ia berada, dengan demikian baik peubah di dalam individu maupun di dalam lingkungan dapat menunjang atau dapat menghambat upaya kreatif. Upaya yang dapat dilakukan untuk meningkatkan ke- mampuan kreatif seseorang ialah melalui pendidikan. Pendapat ahli menyatakan bahwa $67 \%$ dari kemampuan kreativitas seseorang diperoleh melalui pendidikan, $33 \%$ sisanya berasal dari genetik. Guru dapat membuat peserta didik berani berpikir kreatif. Simonton menyatakan bahwa "Great thinkers tends to have great teacher". Pernyataan ini mengandung arti bahwa betapa besarnya peran guru dalam perkembangan kreativitas anak didiknya (Noer, 2009). Seseorang yang memiliki kemampuan berpikir kreatif tinggi dapat menghadapi tantangan masa depan dalam era globalisasi dan canggihnya teknologi serta komu- 
nikasi. Selain itu kemampuan berpikir kreaitf dapat menjadi bekal dalam menghadapi persoalanpersoalan dalam kehidupan (Liliawati, 2011).

Di Indonesia, kurikulum pendidikan yang saat ini digunakan adalah Kurikulum 2013. Kurikulum 2013 merupakan perkembangan dari KTSP (Kurikulum Tingkat Satuan Pendidikan). Adanya perubahan pada kurikulum yang berlaku akan memberikan perubahan terhadap semua penyelenggara pendidikan, terutama guru dan siswa. Pada Kurikulum 2013, siswa dituntut untuk aktif dalam kegiatan pembelajaran dan guru sebagai fasilitator. Kurikulum 2013 menginginkan siswa kreatif, inovatif dan produktif.

Kegiatan pembelajaran selama ini masih berupa pemberian tugas terstruktur dari guru sehingga siswa tidak dapat mengembangkan idenya karena jawaban dari tugas tersebut terkesan kaku. Kegiatan pembelajaran kurang memfasilitasi siswa untuk mengembangkan keterampilan berpikirnya. Permasalahan tersebut dapat diselesaikan salah satunya dengan cara melibatkan siswa untuk lebih aktif dalam pembelajaran. Adanya kurikulum 2013 ini, siswa dapat melakukan proses pemikiran secara divergen dan imajinatif. Siswa dapat mengajukan pertanyaan/permasalahan terbuka yang dapat menimbulkan minat dan rasa ingin tahu. Penerapan cara ini membuat kemampuan berpikir kreatif berkembang dan mewujudkan kreativitas siswa. Pertanyaan atau permasalahan yang diajukan tentunya harus dirancang sedemikian rupa sehingga siswa dapat terlibat di dalamnya (Liliawati, 2011).

Keterampilan berpikir kreatif adalah keterampilan kognitif untuk memunculkan dan mengembangkan gagasan baru, ide baru sebagai pengembangan dari ide yang telah lahir sebelumnya dan keterampilan untuk memecahkan masalah secara divergen (dari berbagai sudut pandang). Keterampilan berfikir kreatif mencakup empat aspek yaitu: (1) fluency (berpikir lancar), (2) flexibility (berpikir luwes), (3) originality (orisinalitas berpikir), (4) elaboration (penguraian) (Putra, Rinanto, Dwiastuti, \& Irfa, 2016).

Menurut National Advisory Committees UK (1999), bahwa kreativitas memiliki empat karakteristik, yaitu: (1) berfikir dan bertindak secara imajinatif, (2) seluruh aktivitas imajinatif itu me- miliki tujuan yang jelas; (3) melalui suatu proses yang dapat melahirkan sesuatu yang orisinal; dan (4) hasilnya harus dapat memberikan nilai tambah. Keempat karakteristik tersebut merupakan satu kesatuan yang akan bermakna ketika semua karakter tersebut dimiliki seseorang.

Siswono mengungkapkan bahwa Tingkat Kemampuan Berpikir Kreatif (TKBK) yaitu, Tingkat ke-4 (sangat kreatif): siswa mampu menunjukkan kefasihan, fleksibilitas, dan kebaruan atau kebaruan dan fleksibilitas dalam memecahkan masalah, Tingkat ke-3 (kreatif): siswa mampu menunjukkan kefasihan dan kebaruan atau kefasihan dan fleksibilitas dalam memecahkan masalah, Tingkat ke-2 (cukup kreatif): siswa mampu menunjukkan kebaruan atau fleksibilitas dalam memecahkan masalah, Tingkat ke-1 (kurang kreatif), siswa mampu menunjukkan kefasihan dalam memecahkan masalah, dan Tingkat ke-0 (tidak kreatif), siswa tidak mampu menunjukkan ketiga aspek indikator berpikir kreatif (Lisliana et al., 2016).

Tingkat kemampuan berpikir kreatif siswa SMP di Surakarta pada mata pelajaran matematika berada pada tingkat 2 yaitu dalam kategori cukup kreatif (Machromah, Riyadi, \& Usodo, 2015). Apabila kemampuan kreatif sudah tumbuh maka siswa diharapkan mampu mengembangkan kreativitasnya. Siswa perlu diberi kesempatan beraktifitas secara kreatif dan guru hendaknya dapat merangsang siswa untuk melibatkan dirinya dalam kegiatan kreatif. Guru perlu mengusahakan sarana dan prasarana yang diperlukan. Hal yang dapat dilakukan adalah memberi kebebasan kepada siswa untuk mengekspresikan dirinya secara kreatif, tanpa merugikan orang lain atau lingkungan. Agar dapat mengajarkan kreativitas, guru harus kreatif dalam merencanakan cara mengajar, cara memberi tugas, cara menilai dan sebagainya.

\section{METODE PENELITIAN}

Penelitian ini merupakan penelitian deskriptif dengan pendekatan kuantitatif untuk mendeskripsikan profil berpikir kreatif siswa salah satu SMP Negeri di Surakarta. Penelitian ini dilaksanakan pada semester genap tahun ajaran 2017/2018 di 
kelas VII dan VIII salah satu SMP Negeri di Surakarta. Populasi dalam penelitian ini adalah siswa kelas VII dan VIII salah satu SMP Negeri di Surakarta dengan rata-rata 25 siswa tiap kelas. Teknik pengambilan sampel dalam penelitian ini adalah stratified random sampling, yaitu teknik pengambilan data dengan memperhatikan pertimbangan tertentu seperti penggolongan atau pengelompokkan populasi menurut karakteristik tertentu. Sampel penelitian diambil sejumlah 24 siswa dari kelas VII dan 26 siswa dari kelas VIII SMP.

Teknik pengumpulan data pada penelitian ini adalah teknik pengukuran berupa tes tertulis (tes kemampuan berpikir kreatif untuk aspek analisis) berbentuk uraian yang dikembangkan oleh Dian Purnama Sari (2017) yang telah teruji validitas dan reliabilitasnya. Indikator kemampuan berpikir kreatif yang diukur meliputi keaslian, keluwesan, kelancaran dan keterincian.

Data diperoleh dari hasil tes tertulis berupa pilihan ganda 4 soal. Waktu pengerjaan soal selama 30 menit dengan aturan siswa mengerjakan secara mandiri di kelas dan diawasi oleh peneliti.

Teknik analisis data yang dilakukan yaitu statistik deskriptif berdasarkan tingkat berpikir kreatif secara umum dan indikator berpikir kreatif yaitu kelancaran, keluwesan, keaslian, dan kerincian. Teknik analisis data melalui tiga tahap. Tahap pertama adalah mengelompokkan tingkat berpikir siswa berdasarkan jawaban siswa dan indikator keterampilan berpikir kreatf. Tahap keuda adalah rekapitulasi nilai dan presentase tingkat berpikir kreatif siswa. Tahap terakhir adalah analisis tingkat berpikir siswa SMP salah satu SMP Negeri di Surakarta.

Penilaian hasil tes dilakukan dengan rentang skor $0-4$, dengan jumlah total soal 4 nomor yang masing-masing mengacu pada indicator berpikir kreatif yaitu kelancaran, keluwesan, keaslian, dan kerincian. Kemudian skor diolah dalam bentuk nilai dengan rentang $0-100$. Rumus pengolahan skor menjadi nilai sebagai berikut:

$$
\text { Nilai }=\frac{\text { skor yang diperoleh }}{\text { total skor }} \times 100
$$

Nilai yang diperoleh setiap siswa kemudian dikelompokkan menjadi lima tingkatan kreativitas berdasarkan Siswono (2008) :

Tabel 1.

Tingkatan Kreativitas Siswa

\begin{tabular}{cc}
\hline \hline Tingkat Kategori & Interval \\
\hline Tingkat 4 (Sangat Kreatif) & Skor : $76-100$ \\
Tingkat 3 (Kreatif) & Skor : $51-75$ \\
Tingkat 2 (Cukup Kreatif) & Skor : $26-50$ \\
Tingkat 1 (Kurang Kreatif) & Skor : $1-25$ \\
Tingkat 0 (Tidak Kreatif) & Skor : 0 \\
\hline
\end{tabular}

\section{HASIL DAN PEMBAHASAN}

Tabel 2.

Hasil Rata-Rata Tingkatan Berpikir Kreatif Per Indikator Salah Satu SMP Negeri di Surakarta

\begin{tabular}{ll}
\hline \hline Indikator & Nilai Rata-Rata \\
\hline Kelancaran & 1,4 \\
Keluwesan & 1 \\
Keaslian & 1,6 \\
Keterincian & 1 \\
\hline
\end{tabular}

Berdasarkan tabel 2 diketahui bahwa perolehan nilai rata-rata siswa salah satu SMP Negeri di Surakarta pada indikator kelancaran sebesar 1,4 yang berada pada kategori kurang, indikator keluwesan sebesar 1 yang berada pada kategori rendah, indikator keaslian sebesar 1,6 yang berada pada kategori kurang, dan indikator keterincian sebesar 1 yang berada pada kategori rendah.

Hasil nilai rata-rata siswa per indikator tersebut dapat dirinci berdasarkan tingkatan kelasnya seperti tabel di bawah ini:

Tabel 3.

Hasil Rata-Rata Tingkatan Berpikir Kreatif Siswa Kelas VII Per Indikator

\begin{tabular}{ll}
\hline \hline Indikator & Nilai Rata-Rata \\
\hline Kelancaran & 1 \\
Keluwesan & 0,95 \\
Keaslian & 2,5 \\
Keterincian & 0,95 \\
\hline
\end{tabular}

Berdasarkan tabel 3 diketahui bahwa perolehan nilai rata-rata siswa kelas VII pada indikator kelancaran sebesar 1 yang berada pada kategori rendah, indikator keluwesan sebesar 0,95 yang berada pada kategori rendah, indikator keaslian sebesar 2,5 yang berada pada kategori sedang, dan indikator keterincian sebesar 0,95 yang ber- 
ada pada kategori rendah.

Tabel 4.

Hasil Rata-Rata Tingkatan Berpikir Kreatif Siswa Kelas VIII Per Indikator

\begin{tabular}{ll}
\hline \hline Indikator & Nilai Rata-Rata \\
\hline Kelancaran & 1,8 \\
Keluwesan & 1,2 \\
Keaslian & 0,6 \\
Keterincian & 1,2 \\
\hline
\end{tabular}

Berdasarkan tabel 6 diketahui bahwa perolehan nilai rata-rata siswa kelas VIII pada indikator kelancaran sebesar 1,8 yang berada pada kategori kurang, indikator keluwesan sebesar 1,2 yang berada pada kategori kurang, indikator keaslian sebesar 0,6 yang berada pada kategori rendah, dan indikator keterincian sebesar 1,2 yang berada pada kategori kurang.

Tabel 5.

Presentase Berpikir Kreatif Salah Satu SMP Negeri di Surakarta

\begin{tabular}{ll}
\hline \multicolumn{2}{c}{ Surakarta } \\
\hline Kategori & Presentase \\
\hline Sangat Kreatif & $2 \%$ \\
Kreatif & $8 \%$ \\
Cukup Kreatif & $54 \%$ \\
Kurang Kreatif & $34 \%$ \\
Tidak Kreatif & $2 \%$ \\
Jumlah & $100 \%$ \\
\hline \hline
\end{tabular}

Berdasarkan tabel 5 diketahui bahwa tingkat berpikir kreatif siswa salah satu SMP Negeri di Surakarta pada kategori sangat kreatif sebesar $2 \%$, pada kategori kreatif sebesar $8 \%$, pada kategori cukup kreatif sebesar 54\%, pada kategori kurang kreatif sebesar 34\%, dan pada kategori tidak kreatif sebesar $2 \%$. Rata-rata tingkat berpikir kreatif siswa salah satu SMP Negeri di Surakarta berada pada kategori cukup kreatif.

Tabel 6.

Presentase Berpikir Kreatif Siswa Kelas VII

\begin{tabular}{ll}
\hline \hline Kategori & Presentase \\
\hline Sangat Kreatif & $0 \%$ \\
Kreatif & $4,16 \%$ \\
Cukup Kreatif & $75 \%$ \\
Kurang Kreatif & $16,68 \%$ \\
Tidak Kreatif & $4,16 \%$ \\
Jumlah & $100 \%$ \\
\hline
\end{tabular}

Berdasarkan tabel 6 dapat diketahui bahwa tingkat berpikir kreatif siswa kelas VII salah satu SMP Negeri di Surakarta pada kategori sangat kreatif sebesar $0 \%$, pada kategori kreatif sebesar $4,16 \%$, pada kategori cukup kreatif sebesar $75 \%$, pada kategori kurang kreatif sebesar 16,68\%, dan pada kategori tidak kreatif sebesar 4,16\%.

Berdasarkan hasil perhitungan tersebut diperoleh bahwa rata-rata siswa kelas VII salah satu SMP Negeri di Surakarta berada pada kategori cukup kreatif dengan presentase $75 \%$ atau sebanyak 18 siswa dari 24 siswa.

Tabel 7.

Presentase Berpikir Kreatif Siswa Kelas VII

\begin{tabular}{ll}
\hline \hline Kategori & Presentase \\
\hline Sangat Kreatif & $3,9 \%$ \\
Kreatif & $11,5 \%$ \\
Cukup Kreatif & $34,6 \%$ \\
Kurang Kreatif & $50 \%$ \\
Tidak Kreatif & $0 \%$ \\
Jumlah & $100 \%$ \\
\hline
\end{tabular}

Berdasarkan tabel 7 dapat diketahui bahwa tingkat berpikir kreatif siswa kelas VIII salah satu SMP Negeri di Surakarta pada kategori sangat kreatif sebesar 3,9\%, pada kategori kreatif sebesar $11,5 \%$, pada kategori cukup kreatif sebesar $34,6 \%$, pada kategori kurang kreatif sebesar $50 \%$, dan pada kategori tidak kreatif sebesar $0 \%$.

Berdasarkan hasil perhitungan tersebut diperoleh bahwa rata-rata siswa kelas VIII salah satu SMP Negeri di Surakarta berada pada kategori kurang kreatif dengan presentase $75 \%$ atau sebanyak 13 siswa dari 26 siswa.

Berdasarkan hasil tes yang diperoleh menunjukkan bahwa adanya perbedaan yang signifikan antara tingkat berpikir kreatif siswa kelas VII dengan siswa kelas VIII. Hasil menunjukkan bahwa rata-rata tingkat berpikir kreatif siswa kelas VII berada pada kategori cukup kreatif sedangkan siswa kelas VIII kurang kreatif.

Perbedaan tingkat kreativitas disebabkan beberapa faktor yang dapat dibagi menjadi dua garis besar yaitu faktor dari dalam diri siswa (faktor internal) dan faktor dari luar diri siswa (faktor eksternal):

A. Faktor Internal

Faktor internal yang mempengaruhi keterampilan berpikir kreatif siswa adalah sebagai berikut:

1) Jenis kelamin

Tingkat kreativitas seseorang dapat juga 
dipengaruhi oleh jenis kelamin. Anak lakilaki cenderung memiliki keterampilan berpikir lebih baik dibandingkan anak perempuan terutama ketika masa berlalunya kanak-kanak. Anak laki-laki biasanya dituntut untuk lebih mandiri dan dituntut untuk mengambil keputusan yang orisinil dibandingkan anak perempuan sehingga tingkat kreativitas anak laki-laki lebih baik dibandingkan dengan anak perempuan (Hurlock, 1990), namun jenis kelamin ini tidak mempengaruhi kreativitas secara signifikan karena ada faktor lain yang dipertimbangkan (Okyranida, Suparmi, \& Nonoh Siti Aminah, 2017)

\section{2) Umur}

Umur mempengaruhi kreativitas anak dalam hal bahasa, menggambar dan kepribadian (Okyranida, Suparmi, \& Nonoh Siti Aminah, 2017). Imajinasi, rasa ingin tahu, kemandirian, menjalankan resiko, dan menjalankan komitmen tugas (Okyranida, Suparmi, \& Nonoh Siti Aminah, 2017). Semakin tinggi umur seseorang maka semakin tinggi pula kemandirian, menjalankan resiko dan menjalankan komitmen tugas. Namun, umur hanya mempengaruhi kreativitas anak dalam hal bahasa, menggambar dan kepribadian sedangkan dalam penelitian ini kreativitas yang kami ujikan berupa tes tertulis dengan pilihan ganda tanpa memasukkan indikator menggambar dan kepribadian.

\section{3) Hasil belajar kognitif dan gaya kognitif} individu

Siswa dengan hasil belajar kognitif tinggi mampu mengingat fakta-fakta, rumus, pengertian dalam materi pembelajaran serta mampu mengaplikasikan teori dalam kehidupan sehari-hari (Okyranida, Suparmi, \& Nonoh Siti Aminah, 2017).

Gaya kognitif individu merupakan cara penerimaan, pengorganisasian, pemrosesan, dan penggambaran informasi seseorang. Gaya kognitif individu dibedakan menjadi dua, yaitu gaya kognitif impulsif dan reflektif. Karakteristik anak bergaya kognitif impulsif adalah cepat mereson sesuatu tanpa mencer- mati terlebih dahulu sehingga jawaban cenderung salah, sedangkan karakeristik anak bergaya kognitif reflektif adalah mempertimbangkan banyak alternatif solusi sebelum merespon sehingga jawaban cenderung benar. Anak bergaya kognitif impulsif memiliki keterampilan kreatif rendah sedangkan anak bergaya kognitif reflektif memeiliki keterampilan kreatif tinggi (Khamida, Edy Bambang Irawan, \& Hery Susanto, 2017)

\section{4) Hasil psikomotor individu}

Siswa dengan hasil psikomotor tinggi mampu merancang, mendesain, mengombinasikan dan membuat penyelesaian baik pada ekperimen ataupun pembuatan proyek Hasil psikomotor individu berbanding lurus dengan keterampilan kreatif sehingga siswa dengan hasil psikomotor tinggi memiliki keterampilan kreatif yang tinggi (Okyranida, Suparmi, \& Nonoh Siti Aminah, 2017)

\section{B. Faktor Eksternal}

Sedangkan faktor eksternal yang mempengaruhi keterampilan berpikir kreatif siswa adalah sebagai berikut:

1) Model / strategi / pendekatan pembelajaran

Model pembelajaran dapat mempengaruhi tingkat kreativitas siswa. Siswa yang diajar dengan menggunakan pendekatan student center cenderung memiliki tingkat kreativitas yang lebih tinggi dibandingkan siswa yang dijarkan dengan pendekatan teacher center. Pembelajaran student center membiasakan siswa untuk aktif berpikir sehingga ide atau gagasan siswa dapat tersalurkan, namun pada pendekatan teacher centered siswa menjadi pasif sehingga ide atau gagasan kurang tersalurkan (Amtiningsih, Sri Dwiastuti, \& Dewi Puspita Sari, 2016).

\section{2) Lingkungan keluarga}

Lingkungan keluarga mempengaruhi berpikir tingkat tinggi siswa karena lingkungan keluarga merupakan lingkungan siswa pertama kali mendapatkan ilmu, pembentukan karakter dan pembentukan pola pikir anak. 
Semakin kondusif lingkungan keluarga maka semakin tinggi berpikir tingkat tinggi siswa. Besarnya pengaruh lingkungan keluarga terhadap keterampilan berpikir tingkat tinggi adalah 8,94\% (Kurniawan \& Enok Maryani, 2015).

Kemampuan berpikir tingkat tinggi mencakup kemampuan kritis, kreatif, logis, reflektif, metakognitif (Saregar, Sri Latifah, \& Meisita Sari, 2016), sehingga berpikir kreatif juga dipengaruhi oleh lingkungan keluarga.

\section{3) Lingkungan sekolah}

Lingkungan sekolah mempengaruhi berpikir tingkat tinggi siswa. Semakin kondusif lingkungan sekolah maka semakin tinggi berpikir tingkat tinggi siswa. Besarnya pengaruh lingkungan sekolah terhadap keterampilan berpikir tingkat tinggi adalah 1,21\% (Kurniawan \& Enok Maryani, 2015).

Kemampuan berpikir tingkat tinggi mencakup kemampuan kritis, kreatif, logis, reflektif, metakognitif (Saregar, Sri Latifah, \& Meisita Sari, 2016), sehingga berpikir kreatif juga dipengaruhi oleh lingkungan sekolah.

\section{KESIMPULAN}

Hasil penelitian menunjukkan keterampilan berpikir siswa secara umum dalam kategori cukup kreatif, dengan capaian indikator kelancaran sebesar 1,4, keluwesan sebesar 1, keaslian sebesar 1,6, dan keterincian sebesar 1. Rata-rata tingkat berpikir kreatif siswa kelas VII berada pada kategori cukup kreatif sedangkan siswa kelas VIII kurang kreatif. Perbedaan tingkat berpikir kreatif disebabkan oleh faktor internal seperti jenis kelamin, umur, hasil belajar kogitif, gaya kognitif individu dan hasil psikomotor individu. Sedangkan faktor eksternal penyebab perbedaan tingkat berpikir kreatif adalah model/strategi pembelajaran, lingkungan keluarga dan lingkungan sekolah.

\section{DAFTAR PUSTAKA}

Amtiningsih, S., Dwiastuti, S., \& Sari, D. P. (2016). Peningkatan Kemampuan Berpikir
Kreatif melalui Penerapan Guided Inquiry dipadu Brainstorming pada Materi Pencemaran Air. Proceeding Biology Education Conference, 13(1), 868-872.

Hurlock, E. (1990). Perkembangan Anak. Jakarta : Erlangga.

Khamida, A. N., Edy Bambang Irawan, \& Hery Susanto. (2017). Berpikir Kreatif Siswa Impulsif. Prosiding SI MaNIs (Seminar Nasional Integrasi Matematika dan Nilai Islami), 591-596.

Kurniawan, T., \& Enok Maryani. (2015). Pengaruh Lingkungan Keluarga dan Lingkungan Sekolah terhadap Keterampilan Berpikir Tingkat Tinggi Peserta Didik dalam Pembelajaran IPS. JPIS, Jurnal Pendidikan Ilmu Sosial, 209-216.

Liliawati, W. (2011). Pembekalan Keterampilan Berpikir Kreatif Siswa SMA melalui Pembelajaran Fisika Berbasis Masalah. Jurnal Pengajaran MIPA, 16(2), 93-98.

Lisliana, Hartoyo, A., \& Bistari. (2016). Analisis Kemampuan Berpikir Kreatif Siswa dalam Menyelesaikan Masalah pada Materi Segitiga di SMP. Jurnal Pendidikan dan Pembelajaran. 5(11) 1-11.

Machromah, I. U., Riyadi, \& Usodo, B. (2015). Analisis Proses dan Tingkat Berpikir Kreatif Siswa SMP dalam Memecah Masalah Bentuk Soal Cerita Materi Lingkaran Ditinjau dari Kecemasan Matematika. Jurnal Elektroni

Noer, S. H. (2009). Kemampuan Berpikir Kreatif Matematis. Prosiding Seminar Nasional Penelitian, Pendidikan Dan Penerapan MIPA, 521-526.

Okyranida, I. Y., Suparmi, \& Nonoh Siti Aminah. (2017). Pembelajaran Fisika Problem Based Learning (PBL) Menggunaka Metode Eksperimen dan Metode Proyek Ditinjau dari Kemampuan Berpikir Abstrak dan Kemampuan Berpikir Kreatif Siswa SMP/MTs Kelas VIII pada Materi Cahaya. JURNAL INKUIRI, 91-102

Putra, R. D., Rinanto, Y., Dwiastuti, S., \& Irfa, I. (2016). Peningkatan Kemampuan Berpikir Kreatif Siswa melalui Model Pembelajaran Inkuiri Terbimbing pada Siswa Kelas XI MIA 1 SMA Negeri Colomadu Karanganyar Tahun Pelajaran 2015 / 2016 The Increasing of Students Creative Thinking Ability Through 
of Inquiry Learni. Proceeding Biology

Education Conference, 13(1), 330-334.

Saregar, A., Sri Latifah, \& Meisita Sari. (2016).

Efektivitas Model Pembelajaran CUPs:

Dampak terhadap Kemampuan Berpikir

Tingkat Tinggi Peserta Didik Madrasah

Aliyah Mathla'ul Anwar Gisting Lampung. Jurnal Ilmiah Pendidikan Fisika Al-BiRuNi, 233-243.

Sari, Dian Purnama. (2017). Pengaruh Metode Diskusi terhadap Keterampilan Berpikir Kreatif Siswa pada Materi Virus Kelas X di SMA Negeri 5 Palembang. Skripsi. Fakultas Ilmu Tarbiyah dan Keguruan. Universitas Islam Negeri Raden Fatah Palembang.

Siswono, T. Y. E. (2008). Model Pembelajaran Matematika Berbasis Pengajuan dan Pemecahan Masalah untuk Meningkatkan Kemampuan Berfikir Kreatif. Surabaya: Unesa Pres. 